\title{
The Construction and Thinking on Entrepreneurship Pilot Classes in Vocational Education
}

\author{
— Taking Wuxi Institute of Technology As an Example
}

\author{
Bai Jing-lan, \\ Wuxi Institute of Technology Wuxi, Jiangsu 214121 \\ E-mial:baijinglan@163.com
}

\begin{abstract}
In 2010, Wuxi Institute of Technology begun to build the pilot classes of innovation and entrepreneurship aiming at training and educate comprehensive talents with certain sense of innovation and entrepreneurship. The pilot classes combine the innovation and entrepreneurship education with the talent cultivation targets highly, while taking the form of small classes and mentoring. Taking the venture pilot classes of the marketing professional as an example, this paper gives a comprehensive review of the construction of entrepreneurship classes in the last three years from aspects of formation, development and achievement. Moreover, the success factors of entrepreneurship education are also summarized.
\end{abstract}

\section{Keywors-entrepreneurship, development, thinking}

\section{INTRODUCTION}

Wuxi Institute of Technology has launched the " The implementation plan for innovation and entrepreneurship education project" since 2004. Through a series of measures, such as "curriculums introduction, platform building, project setting, mechanism creating", the entrepreneurship education activities were launched omnidirectionally and the college students were encouraged and supported actively to engage in the innovation and entrepreneurial activities. The entrepreneurship education work has been further promoted since the college was named national demonstration vocational colleges project construction unit in 2006. In 2010, the college began to implement the pilot Innovation and Entrepreneurship Education and the College of Economics and Management was to be responsible for the formation of entrepreneurial pilot classes. From the practice in the last three years, a little success was achieved, while a certain insufficiency did exist.

\section{CONSTRUCTION OF ENTREPRENEURSHIP ClASSES}

The steps to construct a entrepreneurship pilot class are as follows.

(1) Preach. To publicize and recommend the new mode of entrepreneurship education in our college, that is, the entrepreneurship class to the new coming students and their parents by means of posters, staff explanation and so on to make them fully understand the mission and

\author{
Zhu ai-sheng \\ Wuxi Institute of Technology Wuxi, Jiangsu 214121 \\ E-mial:baijinglan@163.com
}

philosophy of the entrepreneurial class. On this basis, the running mode and preliminary achievements of the entrepreneurial classes should be highlighted and explained through lectures, Q \& A, and other forms so as to encourage students with insight to participate in.

(2) Sign up. Freshmen of the whole college, regardless of the profession, province and sex, if only they get a certain number of points exceeding the provinces specialist admission control lines (for example: 70 points higher than the control line of Jiangsu Province, while 100 points higher for the students of external provinces in 2012), all have the enrollment eligibility.

(3) Screening and formation. The members are ranked comprehensively according to the four aspects of college entrance examination scores, psychological test, physical test as well as interview. The top 24 students are selected to formulate a small-class teaching and administrative class. The students can achieve the marketing professional diploma after three years of study.

\section{DEVELOPMENT OF ENTREPRENEURSHIP CLASSES}

A. Development of Personnel training program.

(1) The personnel training program must meet the need of social development. During the development of personnel training program, more emphasis has been given on the cultivation of students' comprehensive ability and entrepreneurial awareness. Therefore, there are obvious differences between the entrepreneurship classes and regular classes in terms of training objectives, curriculum setting and so on. Taking the 2012 entrepreneurship classes and ordinary classes of marketing professional as an example, the differences are listed in the following table 1 clearly. 
TABLE I. COMPARATIVE ANALYSIS OF THE PERSONNEL TRAINING PROGRAM OF THE ENTREPRENEURIAL CLASSES AND REGULAR CLASSES entrepreneur in recent years; to step into one enterprise to understand an industry; to organization and plan one

\begin{tabular}{|c|c|c|c|}
\hline & Entrepreneurial classes & $\begin{array}{l}\text { Regular classes } \\
\end{array}$ & Points of difference \\
\hline $\begin{array}{l}\text { Training } \\
\text { objectives }\end{array}$ & $\begin{array}{l}\text { Through training of market awareness, marketing } \\
\text { capabilities, management capabilities, } \\
\text { entrepreneurial awareness and entrepreneurial } \\
\text { capacities, some psychological qualities of the } \\
\text { graduates such as enterprise, entrepreneurial spirit, } \\
\text { the spirit of exploration, spirit of adventure and so } \\
\text { on are enhanced. The training objectives are } \\
\text { mainly aimed at cultivating a new generation of } \\
\text { high-end entrepreneurial marketing talents who } \\
\text { can endure hardship, be good at marketing, have } \\
\text { knowledge about management, entrepreneurship } \\
\text { and good ethics. }\end{array}$ & $\begin{array}{l}\text { To serve the local economic and social } \\
\text { development of Jiangsu province actively, taking } \\
\text { Wuxi and Suzhou as the entity, and the Yangtze } \\
\text { River Delta region oriented. The training } \\
\text { objectives are mainly aimed at training a new } \\
\text { generation of high-end skills marketing talents } \\
\text { who have an overall development of moral, } \\
\text { intellectual, physical and aesthetic aspects and } \\
\text { with good ethics. Meanwhile, ensuring some of } \\
\text { them with entrepreneurial potential can embark } \\
\text { on the road of successful entrepreneurship. }\end{array}$ & $\begin{array}{l}\text { The entrepreneurial marketing } \\
\text { professionals put more emphasis on the } \\
\text { training of entrepreneurial awareness and } \\
\text { ability, and the exercising of } \\
\text { comprehensive capabilities including the } \\
\text { marketing capabilities, management } \\
\text { capabilities and so on. Moreover, the } \\
\text { requirements of the psychological quality } \\
\text { is also higher. }\end{array}$ \\
\hline Jobs & $\begin{array}{l}\text { 1. The first Jobs for graduates: } \\
\text { (1) Salesman: the main post; } \\
\text { (2) Sales assistant manager; } \\
\text { (3) Business Manager Assistant. } \\
\text { 2. The target Jobs for graduates: } \\
\text { (1) Private entrepreneurs; } \\
\text { (2) Marketing manager; } \\
\text { (3) Business Manager. }\end{array}$ & $\begin{array}{l}\text { 1. The first Jobs for graduates: } \\
\text { (1) Marketing staff: the main job; } \\
\text { (2) Sales administrator; } \\
\text { (3) After-sales service member; } \\
\text { (4) Marketers in other industries. } \\
\text { 2. The target Jobs for graduates: } \\
\text { (1) Private entrepreneurs; } \\
\text { (2) Regional agents; } \\
\text { (3) Regional manager of the industrial } \\
\text { enterprises; large } \\
\text { (4) Department manager in the larger } \\
\text { electromechanical mall; } \\
\text { (5) Manager in small business. }\end{array}$ & $\begin{array}{l}\text { There is no essential difference in the first } \\
\text { main jobs. They are grassroots jobs, } \\
\text { that is, marketers. But the positions } \\
\text { starting point of the entrepreneurship } \\
\text { students' first employment may be higher } \\
\text { than the regular classes, such as be } \\
\text { directly engaged in the post of assistant } \\
\text { manager. There are also not much } \\
\text { difference between both goal posts, but } \\
\text { the entrepreneurship students may get the } \\
\text { goal post earlier. }\end{array}$ \\
\hline $\begin{array}{l}\text { Credit } \\
\text { requirements }\end{array}$ & 159.5 credits & 156.5 credits & $\begin{array}{l}\text { Because of the same school time, the total } \\
\text { credits of the entrepreneurial class is } \\
\text { slightly higher, } 3 \text { credits per semester } 0.5 \\
\text { credits higher. }\end{array}$ \\
\hline $\begin{array}{l}\text { Theory } \\
\text { courses }\end{array}$ & 35courses(mainly in 32hours and 48hours) & 33courses(mainly in 48 hours) & $\begin{array}{c}\text { The entrepreneurial class has broader } \\
\text { courses including marketing, accounting, } \\
\text { statistics, management, legal (economic } \\
\text { law), business knowledge, team } \\
\text { management and so on. They also put } \\
\text { forward higher requirements on risk } \\
\text { management and project management as } \\
\text { well. }\end{array}$ \\
\hline $\begin{array}{l}\text { Practice } \\
\text { Courses }\end{array}$ & 16 courses & 7 courses & $\begin{array}{l}\text { Entrepreneurial classes have significantly } \\
\text { more training projects than the regular } \\
\text { classes. And the entrepreneurship } \\
\text { education ranged from the } \\
\text { "entrepreneurial simulation workout” to } \\
\text { the "entrepreneurial professional } \\
\text { internship”, then to the “comprehensive } \\
\text { entrepreneurial training”, represents the } \\
\text { continuity, operability and cognitive rules } \\
\text { of entrepreneurial training education. }\end{array}$ \\
\hline $\begin{array}{l}\text { Vocational } \\
\text { qualification } \\
\text { certificates }\end{array}$ & At least two & At least one & $\begin{array}{l}\text { Entrepreneurship classes put forward } \\
\text { more requirements on the quality of } \\
\text { students. }\end{array}$ \\
\hline
\end{tabular}

(2) The personnel training program reflects the concept of "ability cultivation based". From the comparative analysis of the personnel training programs mentioned above, we can easily find that the practical aspects get high proportion of lessons, and content-rich, covering a wide range. this is consistent with our with original intention of taking the ability cultivation as the basis. In addition, in the process of personnel training, we attach great importance to the enhancement of overall quality and the ability of students and the "Ten One" project was put forward. That is, to track one graduate of marketing professional who has been a successful special event; to participate in one professional skills contest to promote learning; to achieve one non-professional vocational qualification certificate so as to cultivate compound talents; to take part in one student club to cultivate one interest; to get involved in one topic to enhance researching capacity; to publish one article to enhance the professional standards; to set up one online shop to exercise in practice; to carry out one pioneering attempt to test the learning outcomes.

\section{B. Implementation of entrepreneurship education system}

(1) Small classes and mentoring. Compared with Conventional teaching class whose size is about 40 people, the entrepreneurial class is 24 , each of which is 
excellent student thoroughly screened and tested. The advantages of small classes are convenient management, strong execution and team cohesion as well as high work efficiency. Moreover, it is also easier for teachers to concern the dynamic of each student. What's more, it is more convenient for classroom management and the organization and implementation of teaching content.

The 24 students are divided into four teams, each team with an experienced mentor. The mentor is to give the corresponding students throughout guide in study, practice and other activities in the full three years. Then, each team are required to establish deep cooperation with an enterprise. The mentoring enables students to have definite target for seeking help, and the interaction and communication between the teacher and the student become more direct, convenient and in-depth.

(2) Project-based classroom learning. All teachers teaching specialized courses are required to take a project-based teaching mode. In fact, the project-based teaching is teaching through the implementation of a complete project activities, and its purpose is to organically combine the theory teaching and practice teaching into curriculum teaching to give full play to the creative potential of the students and improve the comprehensive ability of students to solve practical problems by means of clear project tasks, planning, plans implementation, inspection and evaluation as well as feedback improvement.

The reasons why the teachers are required to use the project-based teaching, rather than the traditional mode of teaching is that through the guidance of teachers, the overall quality of students can be further cultivated and enhanced.

(3) Diversification of extracurricular practices. The Extracurricular practices includes the practical aspects of teaching content arranged in teaching plan, a variety of two-curricular activities organized by the school, community activities, social part-time recommended by the tutor as well as skills competitions. It is hoped that through a variety of extra-curricular life, the good moral character can be cultivated, the clear ideals and beliefs can be established, the life experience can be enriched, the vocational skills can be enhanceed and the entrepreneurial spirit can also be achieved.

\section{Achievements}

Entrepreneurship education pilot classes offered in Wuxi Institute of Technology is less than three years since the first venture pilot class was established in September 2010, and the students have not graduated come into society, so it is difficult to judge the success of entrepreneurial pilot education, but it is evident that the average overall quality of these students is much higher than the same grade students, mainly confirmed from the following aspects(the outcomes listed are taken from 41091 class of marketing major).
(1) Honors. Marketing 41091 class has obtained several group honors such as the advanced class group of Wuxi city, the top two of the whole school debate competition, the top three of the bulletin boards competition, the top three of the Ban emblem design contest. The classmates have attended various competitions sponsored by the college and won 14 prizes. Three of them won the national motivational scholarships, and one was entitled as City Miyoshi students, Many of them are also entitled as school outstanding student leaders, three good students, outstanding members and some other honorary titles.

(2) Certificates. All of the 24 students in the class have passed the test of computer band $1 \mathrm{~B}$, the highest pass rate of the whole college. And the pass rates for CET band 3 and 4 are $100 \%$ and 25\% respectively. What's more, the pass rate for vocational qualification certificate test is $100 \%$ and each student has at least two certificates.

(3) Statistics on prizes won in important contests. The whole class have participated in municipal skills competition for several times and won 16 prizes for a total of 42 students. The outcomes are summarized in the following table 2 .

TABLE II. MARKETING 41,091 CLASSES MUNICIPAL CONTEST STATISTICS

\begin{tabular}{|c|c|c|c|c|}
\hline No. & $\begin{array}{c}\text { Prize name } \\
\end{array}$ & Award grade & Winners & Data \\
\hline 1 & $\begin{array}{l}\text { The first prize of the } \\
\text { national } \\
\text { undergraduate } \\
\text { e-commerce } \\
\text { "innovation, creativity } \\
\text { and entrepreneurship" } \\
\text { challenge finals }\end{array}$ & National & $\begin{array}{l}\text { X. Y. Deng, } \\
\text { H.G. Pan }\end{array}$ & $\begin{array}{l}\text { Nov, } \\
2011\end{array}$ \\
\hline 2 & $\begin{array}{l}\text { The second prize of } \\
\text { the national finals of } \\
\text { the fourth National } \\
\text { college marketing } \\
\text { competition and the } \\
\text { marketing } \\
\text { management award }\end{array}$ & National & $\begin{array}{l}\text { X. Y. Deng, } \\
\text { H.G. Pan }\end{array}$ & $\begin{array}{l}\text { Nov, } \\
2011\end{array}$ \\
\hline 3 & $\begin{array}{c}\text { The grand prize of } \\
\text { Wuxi college students } \\
\text { entrepreneurial } \\
\text { abilities series } \\
\text { competition }\end{array}$ & Municipal & $\begin{array}{l}\text { X. Y. Deng, } \\
\text { T. Ling, } \\
\text { H.G. Pan }\end{array}$ & $\begin{array}{l}\text { Jan, } \\
2012\end{array}$ \\
\hline 4 & $\begin{array}{c}\text { The first prize of } \\
\text { Wuxi college students } \\
\text { entrepreneurial } \\
\text { abilities series } \\
\text { competition }\end{array}$ & Municipal & $\begin{array}{l}\text { C. Yang, J. } \\
\text { Wang }\end{array}$ & $\begin{array}{l}\text { Jan, } \\
2012\end{array}$ \\
\hline 5 & $\begin{array}{l}\text { The second prize of } \\
\text { Wuxi college students } \\
\text { entrepreneurial } \\
\text { abilities series } \\
\text { competition } \\
\end{array}$ & Municipal & $\begin{array}{l}\text { M. Q. Fang, } \\
\text { D. D. Gu, Y. } \\
\text { Liu }\end{array}$ & $\begin{array}{l}\text { Jan, } \\
2012\end{array}$ \\
\hline 6 & $\begin{array}{c}\text { The second prize of } \\
\text { Wuxi college students } \\
\text { entrepreneurial } \\
\text { abilities series } \\
\text { competition } \\
\end{array}$ & Municipal & $\begin{array}{c}\text { H. M. } \\
\text { Zhang, C. } \\
\text { L. Shi, S. } \\
\text { W. Shen }\end{array}$ & $\begin{array}{c}\text { Jan, } \\
2012\end{array}$ \\
\hline 7 & $\begin{array}{c}\text { The second prize of } \\
\text { Wuxi college students } \\
\text { entrepreneurial } \\
\text { abilities series }\end{array}$ & Municipal & P. Liu & $\begin{array}{l}\text { Jan, } \\
2012\end{array}$ \\
\hline
\end{tabular}




\begin{tabular}{|c|c|c|c|c|}
\hline & competition & & & \\
\hline 8 & $\begin{array}{c}\text { The third prize of } \\
\text { Wuxi college students } \\
\text { entrepreneurial } \\
\text { abilities series } \\
\text { competition }\end{array}$ & Municipal & $\begin{array}{c}\text { B. Y. Pu, D. } \\
\text { Xu, H. Y. } \\
\text { Han, K. } \\
\text { Zhang }\end{array}$ & $\begin{array}{l}\text { Jan, } \\
2012\end{array}$ \\
\hline 9 & $\begin{array}{l}\text { The first prize (Hong } \\
\text { Kong) accounting and } \\
\text { business management } \\
\text { case study } \\
\text { competition Mainland } \\
\text { universities, and the } \\
\text { finals winner }\end{array}$ & National & C. Yang & $\begin{array}{l}\text { Apr, } \\
2012\end{array}$ \\
\hline 10 & $\begin{array}{l}\text { "Xianlin Science City } \\
\text { - the Challenge Cup" } \\
\text { The seventh session } \\
\text { of Jiangsu province } \\
\text { university student } \\
\text { business plan } \\
\text { competition bronze }\end{array}$ & Provincial & $\begin{array}{l}\text { X. R. Wu, J. } \\
\text { L. Zhu, G. } \\
\text { Z. Guo et al }\end{array}$ & $\begin{array}{l}\text { May, } \\
2012\end{array}$ \\
\hline 11 & $\begin{array}{l}\text { The third prize of } \\
2012 \text { national } \\
\text { undergraduate } \\
\text { business management } \\
\text { sandbox simulation } \\
\text { contest Jiangsu } \\
\text { provincial tournament }\end{array}$ & Provincial & $\begin{array}{l}\text { G. Z. Guo, } \\
\text { H. Y. Han }\end{array}$ & $\begin{array}{l}\text { Aug, } \\
2012\end{array}$ \\
\hline 12 & $\begin{array}{l}\text { The second prize of } \\
\text { the sixth national } \\
\text { commercial colleges } \\
\text { skills competition } \\
\text { marketing } \\
\text { professional contest } \\
\text { finals }\end{array}$ & National & $\begin{array}{l}\text { X. Y. Deng, } \\
\text { C. Yang, T. } \\
\text { Ling }\end{array}$ & $\begin{array}{l}\text { Aug, } \\
2012\end{array}$ \\
\hline 13 & $\begin{array}{l}\text { The third prize of the } \\
\text { sixth national } \\
\text { commercial colleges } \\
\text { skills competition } \\
\text { marketing } \\
\text { professional contest } \\
\text { finals }\end{array}$ & National & X. R. Wu & $\begin{array}{l}\text { Sep, } \\
2012\end{array}$ \\
\hline 14 & $\begin{array}{l}\text { The second prize of } \\
\text { the fifth national } \\
\text { college marketing } \\
\text { competition Jiangsu } \\
\text { province race }\end{array}$ & Provincial & $\begin{array}{l}\text { H. M. } \\
\text { Zhang }\end{array}$ & $\begin{array}{l}\text { Sep, } \\
2012\end{array}$ \\
\hline 15 & $\begin{array}{l}\text { The first prize of the } \\
\text { fifth national college } \\
\text { marketing } \\
\text { competition national } \\
\text { finals } \\
\end{array}$ & National & $\begin{array}{l}\text { W. W. Sun, } \\
\text { D. Xu }\end{array}$ & $\begin{array}{l}\text { Dec, } \\
2012\end{array}$ \\
\hline 16 & $\begin{array}{l}\text { The second prize of } \\
\text { the fifth national } \\
\text { college marketing } \\
\text { competition national } \\
\text { finals }\end{array}$ & National & $\begin{array}{l}\text { X. Y. Deng, } \\
\text { T. Ling, C. } \\
\text { Yang et al }\end{array}$ & $\begin{array}{l}\text { Dec, } \\
2012\end{array}$ \\
\hline
\end{tabular}

(4) Scientific research. Two students from marketing major of 41091 class used to preside over a provincial college students practice innovative training program topics, and two others used to preside over the university-level college students' innovative projects. The specific projects are shown in the following table 3.

TABLE III. STATISTICS ON SCIENTIFIC RESEARCH PROJECTS FROM MARKETING MAJOR OF 41091 CLASS

\begin{tabular}{|c|c|c|c|c|}
\hline No. & Project name & $\begin{array}{c}\text { Project } \\
\text { category }\end{array}$ & $\begin{array}{c}\text { Project } \\
\text { Leader }\end{array}$ & $\begin{array}{c}\text { Project } \\
\text { time }\end{array}$ \\
\hline 1 & $\begin{array}{c}\text { Garden theme } \\
\text { western } \\
\text { restaurant } \\
\text { planning }\end{array}$ & $\begin{array}{c}\text { School-level, } \\
\text { entrepreneurial } \\
\text { technology }\end{array}$ & X. Y. Deng & Jan, 2012 \\
\hline
\end{tabular}

\begin{tabular}{|c|c|c|c|c|}
\hline 2 & $\begin{array}{c}\text { DIY gift } \\
\text { making }\end{array}$ & $\begin{array}{c}\text { School-level, } \\
\text { entrepreneurial } \\
\text { technology }\end{array}$ & Y. Q. Cao & Jan, 2012 \\
\hline 3 & $\begin{array}{c}\text { Students } \\
\text { quality } \\
\text { development } \\
\text { training } \\
\text { Planning - } \\
\text { Wuxi Qiujing } \\
\text { company Wuxi } \\
\text { university } \\
\text { campus } \\
\text { expansion } \\
\text { project } \\
\text { promotion } \\
\text { entrepreneurial } \\
\text { technology }\end{array}$ & T. Ling & Jan, 2012 \\
& copywriter & & & \\
& $\begin{array}{c}\text { Investigation } \\
\text { and analysis of } \\
\text { the status of } \\
\text { college } \\
\text { students } \\
\text { venture in } \\
\text { Wuxi }\end{array}$ & Provincial, & X. Y. Deng & Jun, 2012 \\
& research & & \\
& & & \\
& & & & \\
& & & & \\
\hline
\end{tabular}

(5) Practice of entrepreneurship. All of the 24 students in marketing major of 41091 class obtained Wuxi entrepreneurship training certificate. And the student who owns the certificate will be able to get the subsidized loan of 0.1 million of financial and other business support funding if only he would like to do pioneering work in Wuxi.

All the students in the class opened the online shops during the school study, some of the students even reached the diamond level. The collective of the class have experienced stall entrepreneurial experience. Moreover, 3 of them opened physical stores in entrepreneurship Street.

\section{THINKING AND SUMMARY}

After nearly three years of construction, the entrepreneurship education has accumulated a certain outcome, these achievements are due to the building of perfect entrepreneurship education system, the support and tilt from the school policy, as well as the implementation of principles and policies of the overall quality of education which takes competency culture as the main line.

A. The construction of the entrepreneurship education system is the inherent requirement of the success of entrepreneurship education.

There are many influencing factors which determine whether the entrepreneurship can be a success. The intrinsic factors include entrepreneurial desire, family background, entrepreneurial opportunities as well as entrepreneurial education experience and so on. On the contrary, the external factors consist of policy, environment, culture and ideas as well. The entrepreneurship education experience mainly comes from the entrepreneurship education in colleges.

Nowadays, the entrepreneurship education is widely promoted, and the concept of entrepreneurship education 
has been recognized by the majority of colleges and universities. However, the entrepreneurship education exists in the form of a great deal of diversity, and many colleges have written the entrepreneurship education into teaching programs, while few of them have established the entrepreneurial classes, carried out pilot education or taken the entrepreneurs as the personnel training objectives directly. The biggest difference between the two kind of classes lies in whether the entrepreneurship education was built as a complete educational system. If only for a single course, the generality of entrepreneurship education can be reflected. However, the depth and breadth of education can not meet the requirements because of the lack of integrity. The essence of the development of entrepreneurial talent cultivation programs is the building of entrepreneurship education system, involving training objectives, curriculum system, teaching arrangements, resource-oriented, policy support, supervision and management and so on, resulting in the spiral cycle including planning, implementation, supervision, feedback as well as revision eventually. Therefore, the construction of entrepreneurship education system does good in the improvements of entrepreneurial education mode and the generation of outcomes. What's more, it is the inherent requirement of successful entrepreneurship education.

\section{B.Policy support is the objective need of the success of entrepreneurship education.}

The college has invested a lot of manpower and material resources into the entrepreneurial classes, which also incurred the desirable results from the classes. Firstly, that is the hardware support. The entrepreneurship classes have their dedicated multimedia classrooms and, for this reason, the students have more ways and opportunities to access to information as compared with regular classes. Secondly, that is the teachers resource support. The college attaches great importance to the education of entrepreneurship pilot classes, and the teacher for the pilot classes must be an associate professor or excellent young teachers in principle, and each team is equipped with a mentor. Thirdly, that is the financial support. The college subsidizes the entrepreneurship education of the entrepreneurial classes according to the standard of ten thousands RMB per student per year. In this way, the students have more opportunities in participating in some pay-per-view projects such as extra practical courses of training, entrepreneurial training and so on, achieve more comprehensive education, and enhance the quality faster. Finally, that is the policy support. The college supply large help in housing, venues, business guidance and so on for students devoted in doing pioneering work.

\section{C.The essence of entrepreneurship education is the} education of overall quality.

There are many different perspectives on entrepreneurship education, but the general agreement is that entrepreneurship education is the education to train the capacities of entrepreneurial awareness and entrepreneurial capacity of students, and it is divided into two levels: One is the education on engaging or launching planning, activities and process of the enterprise or business. The other is the education on entrepreneurial mental qualities including enterprise, ambition, exploring spirit, spirit of adventure and so on. That is to say, the entrepreneurship education is not the education which is indeed to start a business, its essence is the education of overall quality, which is set to develop, cultivate and promote the business ability and professional competence of a person (Li Jiahua, Associate Dean and Professor of China Youth Political College). Therefore, in the process of personnel training for entrepreneurship education, more attention has been paid to enhancing the overall quality of students. In addition to the conventional culture quality education activities organized by the college such as various of humanity lectures, the students encourage to participate in various charitable activities, skills competition, social part-time work and entrepreneurial practice so as to enhance the capacities of communication, , in order to enhance communication skills and social experience, and cultivate good psychological quality of students. Moreover, through the execution of the "Ten One" project, the overall capacity of the students are developed comprehensively, and the students achieve both the employment advantages and the entrepreneurial basis.

Entrepreneurship education is not only an assignment, but also a hard problem. It was born out of the need of the society, thus the inspection must be evaluated by the society. It is really a long process form one entrepreneurial class, one entrepreneurial lecture, one entrepreneurial competition to that the entrepreneurship education was written into the personnel training programs and the venture pilot classes were set up, and then to the ultimate formation of entrepreneurial culture and entrepreneurship education system. But it's a great honor to show that we have crossed the key step of putting theory into practice as well as putting slogan into action. The outcomes achieved from running the entrepreneurial pilot classes in nearly three years encourage and urge us to devote ourselves to the implementation of entrepreneurship education.

\section{ACKNOWLEDGEMENT}

This work was supported in part by National Social Science Foundation of China under Grant No. 12BGL021, which is named as "Research on the construction and optimization of enterprise education system in colleges and universities". 


\section{ACKNOWLEDGMENT}

National social science fund project, grant no. 12 bgl021, name: entrepreneurship education system in colleges and universities to build research and optimization

\section{REFERENCES}

[1] Zhang Tianhua. Research on the deep school-enterprise cooperation based on the "combine your study with work" mode[J] Journal of National Academy of Education Administration. Jan, 2012.
[2] Zhang Tianhua. Thinking on the validity of the "full management mode" used in college students work[J]. Journal of China Adult Education. May, 2007.

[3] Zhu Aisheng. The system thinking on China's science and technology innovation system[J]. Journal of Exploring Education Development. Dec, 2007.

[4] Ren Luyao, Yang Zengxiong. Entrepreneurship Education: The third education passport - An overview on the research of foreign entrepreneurship education [J]. Journal of Education Research Monthly. Nov, 2010. 